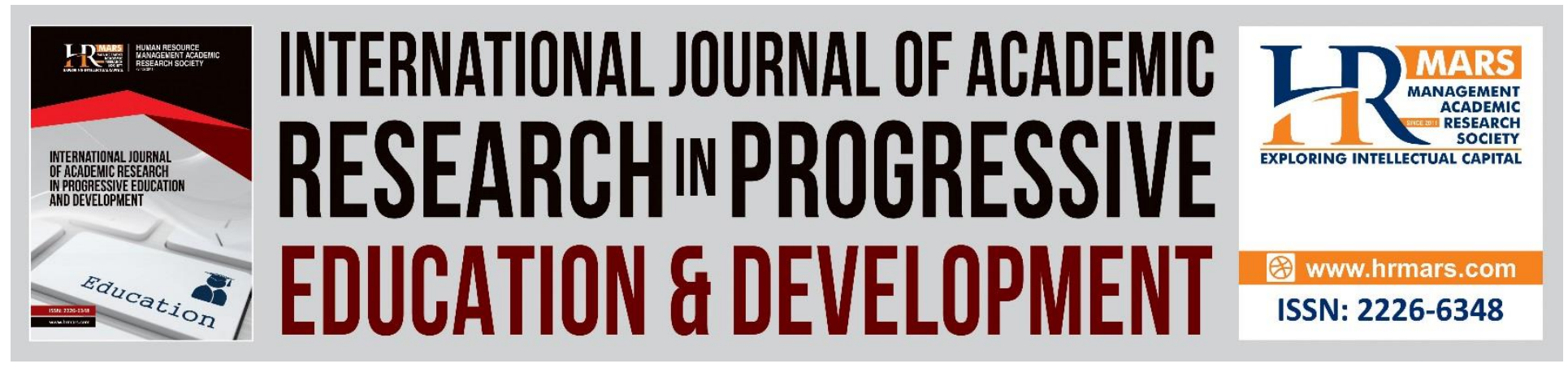

\title{
Social Entrepeneurship and TVET: Tackling Youth Unemployment
}

Zaihana Manshor, Shuhairimi Abdullah, Mohd Azli Takiyudin

To Link this Article: http://dx.doi.org/10.6007/IJARPED/v9-i4/8262

DOI:10.6007/IJARPED/v9-i4/8262

Received: 01 October 2020, Revised: 02 November 2020, Accepted: 15 December 2020

Published Online: 30 December 2020

In-Text Citation: (Manshor et al., 2020)

To Cite this Article: Manshor, Z., Abdullah, S., \& Takiyudin, M. A. (2020). Social Entrepeneurship and TVET:

Tackling Youth Unemployment. International Journal of Academic Research in Progressive Education and

Development, 9(4), 93-98.

Copyright: (C) 2020 The Author(s)

Published by Human Resource Management Academic Research Society (www.hrmars.com)

This article is published under the Creative Commons Attribution (CC BY 4.0) license. Anyone may reproduce, distribute, translate and create derivative works of this article (for both commercial and non-commercial purposes), subject to full attribution to the original publication and authors. The full terms of this license may be seen at: http://creativecommons.org/licences/by/4.0/legalcode

\section{Vol. $9(4)$ 2020, Pg. 93 - 98}

http://hrmars.com/index.php/pages/detail/IJARPED

JOURNAL HOMEPAGE

Full Terms \& Conditions of access and use can be found at http://hrmars.com/index.php/pages/detail/publication-ethics 


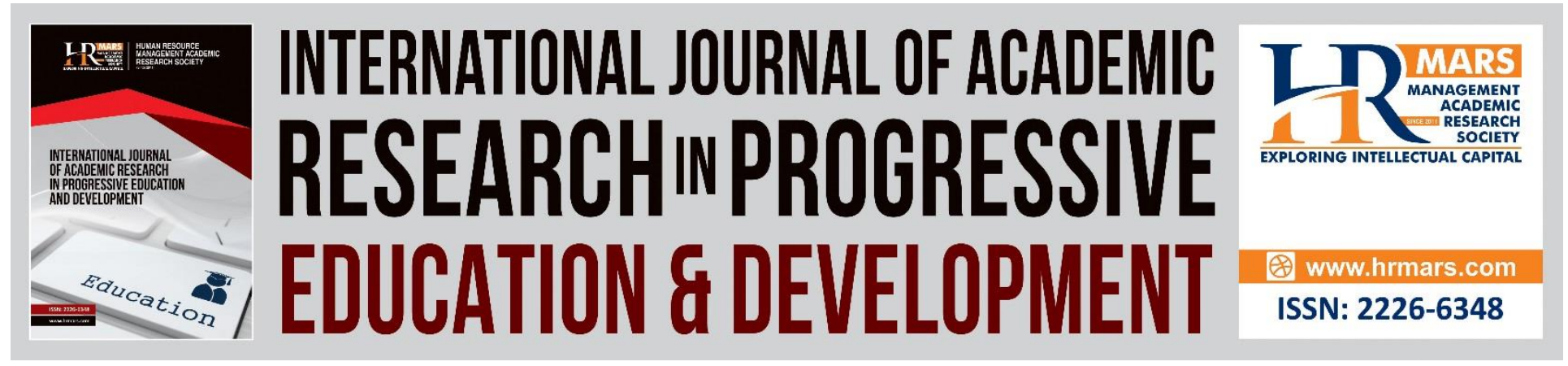

\title{
Social Entrepeneurship and TVET: Tackling Youth Unemployment
}

\author{
Zaihana Manshora, Shuhairimi Abdullah ${ }^{\mathrm{b}}$, Mohd Azli Takiyudin ${ }^{\mathrm{c}}$ \\ aPostgraduate Student ${ }^{\mathrm{b}}$ Senior Lecturer Universiti Malaysia Perlis, ' ${ }^{\mathrm{C}}$ Lecturer Kolej Komuniti \\ Arau Perlis \\ Email: zaihanamans@yahoo.com
}

\begin{abstract}
In the government's efforts to improve the living standards of the people, education and entrepreneurship are the best tools in the economic problems of a society by providing them with extensive knowledge and skills. The main objective of this paper is to look at the relationship between social entrepreneurship and, technical and vocational education and training system (TVET) in solving the unemployment issue faced by youth today. Meanwhile, the research methods used are secondary data sources and documents obtained from online databases and library collections. In conclusion, through the relationship between social entrepreneurship and TVET, the problem of unemployment can be reduced in society in Malaysia

Keywords: Social Entrepreneurship, Technical and Vocational Education and Training (TVET), Unemployment, Youth

\section{Introduction}

Malaysia is a developing country and rich in various resources. Many opportunities and spaces have been provided for every individual in the community to get the best and most comfortable life. The government has become a proactive support system in helping people in need. They should enjoy with high financial potential. However, knowledge and skills are important elements in equipping one's soft skills to use every resource or assistance that has been provided. This is because, in the current era of modernity, there are still many sections of society who face crisis do not have critical jobs, especially the young. Thus, this situation also proves that the unemployment is due to lack of initiative and creativity in themselves. Undoubtedly, the characteristics and skills of entrepreneurship in society also do not show a satisfactory level. For example, the wise attitude of seizing opportunities is very weak in themselves due to the lack of knowledge and basic skills that are very important. There is a Chinese saying, give a fish to a man and you feed him for a day, teach a man to fish and you feed him for life. The government has provided a lot of funds aimed at injecting capital so that it can be fully utilized by venturing into business.
\end{abstract}


Significantly, education and entrepreneurship are two aspects that play a very important role in helping the community especially the youth to get employment opportunities (Saibon, Kamis, \& Zainol, 2019). For example, graduates who find it difficult to place themselves in the labor market, with the entrepreneurial knowledge and skills they possess, can engage in small business. This proactive attitude can save them from unemployment as well as create other business opportunities. Therefore, this article will discuss the relationship between two important aspects, namely social entrepreneurship and education and skills, especially TVET to play a role in overcoming the problem of youth unemployment recently.

\section{Youth Unemployment}

According to Kamus Dewan Bahasa dan Pustaka, unemployment means a situation or thing that does not work. The Department of Statistics Malaysia (2020) defines unemployment as a group of individuals who are interested in working but do not have a job. They are also categorized into two groups namely active unemployed and inactive unemployed. In this context, most of the youths are active because they are graduates of schools and institutions of higher learning who want to enter the career field. This year, the number of unemployed in Malaysia shows an increasing trend. This is because in January 2020 the unemployment rate was 3.2 percent, but this figure increased to 3.3 percent in February 2020 (Department of Statistics Malaysia, 2020). There are projections made expecting the unemployment rate to reach up to 5.5 percent compared to 1986 which is 7.4 percent due to the previous economic downturn. According to the Chief Statistician of Malaysia, Dr. Mohd Uzir Mahidin, until March 2020 the total number of unemployed is 546,600 people. Graduates recorded 29.3 percent of the total. Youths are the largest contributor to this percentage of 6.9 percent compared to the age group of 31 to 45 years (1.4 percent) and 46 to 64 years (1.1 percent) (Harian, 2020). Such statistics prove that youth are the most difficult group and are plagued by this unemployment problem. In general, the main factor contributing to unemployment is due to the inability to compete with each other based on relevant and effective skills (Eichhorst, 2014). In addition, there are also other factors that contribute to this unemployment crisis, namely inappropriate skills or skills mismatches. This involves a lack of practical skills and work experience. However, the main problem is the lack of job opportunities in the labor market is also the cause of this unemployment issue (Subrahmanyam \& Ananiadou, 2013).

\section{Social Entrepreneurship}

Based on previous studies and articles, entrepreneurship is often associated with the unemployment issue in society. Entrepreneurship is seen as a possible solution to this problem. This is because entrepreneurship is considered as the best element in overcoming problems in society since long ago. This is in line with the argument of Gamede \& Uleanya (2018) who argues that the best solution to the issue of unemployment in every stratum of society whether in urban or rural areas is entrepreneurship. Nowadays, the field of entrepreneurship is expanded and combined into various other fields so that it can play a much more effective role for society. One of them is the field of social entrepreneurship. In oversea, social entrepreneurship may have been known for decades. This refers to the well-known website that is Forbes (2019) which places the top three rankings of the best countries for the field of social entrepreneurship are Canada, 
Australia and France. However, in Malaysia, the phenomenon of social entrepreneurship is still considered new and still unknown. Based on the existing literature, there are various understandings and definitions given by various parties related to this field. Among them is defining it from an innovation perspective (Dees \& Anderson, 2006), placing this social entrepreneurship as a profit generating model for social goals (Bagnoli \& Megali, 2011) and no less also argues that this entrepreneurship is also voluntary work (Beckmann \& Zeyen, 2014 ). In short, social entrepreneurship uses an entrepreneurial approach to solve social problems (Ramlee Mustapha, Zapata, \& Jung-Kim, 2008). Nevertheless, Neck et al. (2009) argue that social entrepreneurship is defined into two elements, namely centered on entrepreneurs and process elements. Therefore, in this paper the author will touch on the second element which is the process.

\section{Technical and Vocational Educational and Training (TVET)}

Today, the education system faces various challenges in nurturing and producing knowledgeable and high-quality human capital. Referring to the Entrepreneurship Action Plan (2016-2020), the government takes the initiative in developing the standard and level of education that not only focuses on the academic field, but also focuses on the technical and vocational education and training system (TVET). TVET is an employment-oriented system where it provides employability skills and knowledge to facilitate the transition process from the education system to the world of work (Baxter, Hastings, Law, \& Glass, 2013). In Malaysia, a body was established to recognize the technologists and technicians, namely the Malaysian Board of Technologist (MBOT). In the government's efforts to uphold TVET, in addition to creating the Technologists and Technicians Act 2015 (MBOT, 2017), the education system was also revamped by placing TVET under the ministry of education (Paryono, 2017). Various programs and funds are allocated to many relevant parties such as educational and training institutions for the purpose of improving and meeting the needs of graduates when working later. In today's world of employment, employers prefer candidates who have practical abilities, skills and knowledge related to the type of job applied for, rather than theoretical knowledge and grade achievement in exams only (Hassan, Puteh, Sanusi, \& Salleh, 2018). This shows that the importance of educational institutions take proactive steps in providing competent and potential graduates to meet the needs of the industry. There are various root problems in this issue which is the cause of the difficulties of the youths in placing themselves in the world of work so it leads to the unemployment issue. Mustapha et al (2008) argue that the level of education and training among the rural population is still low. This shows that the lack of exposure and convenience to young people in rural areas makes their life more difficult. In addition, the lack of collaboration and cooperation between educational institutions and industry leads to this problem (Gamede \& Uleanya, 2018). Educational institutions and employers need to have an agreement in matching the candidate with the field of work through the characteristics and competencies that the candidate must have. This is in line with Connor (2014) who emphasizes the element of mentor-mentee in the aspect of career building because cooperation between institutions and experts from industry can produce agreement from various angles in addition to research and development in producing graduates desired by employers. For example, the Memorandum of Understanding 
between Tunku Abdul Razak University (UTAR) and JobStreet in an effort to keep graduates in high demand with prospective employers (The Star, 2020).

\section{Conclusion}

In the nut shell, social entrepreneurship and TVET are able to overcome the problem of unemployment in society, especially the youth. Both of these elements play a role in helping youths get good job opportunities and in line with their skills and knowledge. Through the TVET system, youths whether graduates of school or institutions of higher learning can acquire the knowledge and skills that will be taught by trained instructors. Furthermore, by engaging in the field of social entrepreneurship, youths who are full of skills and knowledge, can help the community through social efforts. For example opening a business that can generate employment opportunities for other unemployed. In addition, they also preserve the environment by using knowledge and skills such as recycling used goods.

\section{Corresponding Author}

Zaihana Manshor

Postgraduate Student, Faculty of Applied and Human Sciences, Universiti Malaysia Perlis (UniMAP), Perlis.

Email: zaihanamans@yahoo.com

\section{References}

Alias A. (2020). Jumlah penganggur meningkat 17.1 peratus. Retrieved from BH Online: https://www.bharian.com.my/bisnes/lain-lain/2020/05/686536/jumlah-penganggur meningkat-171-peratus

Bagnoli, L., \& Megali, C. (2011). Measuring performance in social enterprises. Nonprofit and Voluntary Sector Quarterly. https://doi.org/10.1177/0899764009351111

Baxter, R., Hastings, N., Law, A., \& Glass, E. J. (2013). Tackling youth unemployment through TVET: Report of the UNESCO-UNEVOC online conference. In UNESCO-UNEVOC International Centre for Technical and Vocational Education and Training.

Beckmann, M., \& Zeyen, A. (2014). Franchising as a Strategy for Combining Small and Large Group Advantages (Logics) in Social Entrepreneurship: A Hayekian Perspective. Nonprofit and Voluntary Sector Quarterly. https://doi.org/10.1177/0899764012470758

Eichhorst, W. (2014). Does vocational training help young people find a (good) job? IZA World of Labor. https://doi.org/10.15185/izawol.112

Gamede, B. T., \& Uleanya, C. (2018). Entrepreneurship: Solution to unemployment and development in rural communities. Journal of Entrepreneurship Education.

Hassan, N. F. B., Puteh, S. Bin, Sanusi, A. B. M., \& Salleh, N. N. H. M. (2018). TEAL Application in Training TVET Graduates to Solve the Unemployment Problem. Advance Science Letters. http://doi.org/10.1166/asl.2018.12485

Jabatan Perangkaan Malaysia. (2020). Siaran akhbar statistic utama tenaga buruh di Malaysia, Februari 2020, pp.1-4. 
Dees, J. G., \& Anderson, B. B. (2006). Framing a Theory of Social Entrepreneurship: Building on two schools of practice and thought. Research on Social Entrepreneurship: Understanding and Contributing to an Emerging Field. https://doi.org/10.1002/nml.43

MBOT penuhi keperluan mendepani Revolusi Perindustrian 4.0. (2017, Disember 14). Retrieved from Malaysian Board of Technologist: https://www.mbot.org.my/media/news/mbot penuhi-keperluan-mendepani-revolusi-perindust/

Mohamad, H. F. (2020). Kadar pengangguran diunjur 5.5 peratus tahun ini. Retrieved from BH Online: https://www.bharian.com.my/bisnes/lainlain/2020/05/688828/kadarpengangguran-diunjur-55-peratus-tahun-ini

Paryono. (2017). The importance of TVET and its contribution to sustainable development. AIP Conference Proceedings. https://doi.org/10.1063/1.5003559

Saibon, R. A., Kamis, A., \& Zainol, Z. (2019). Entrepreneurship education: Unemployment issues, people's wellbeing and entrepreneurial intentions among TVET graduates in Malaysia. International Journal of Psychosocial Rehabilitation. https://doi.org.10.37200/ijpr/v23i4/pr190423

Subrahmanyam, G., \& Ananiadou, K. (2013). Tackling youth unemployment through TVET: Report of the UNESCO-UNEVOC online conference. Retrieved from www.unevoc.unesco.org

Tran, K. (2019). The best country to be a social entrepreneur in 2019. Retrieved August 20, 2020, from Forbes: https://www.forbes.com/sites/khaitran/2019/10/26/the-best-country-to -be-a-social-entrpreneur-in-2019/\#6787e2c6dd37 